\title{
Profile of metals Fe in lay ecosystem using ICP-OES in Donggala District, Indonesia
}

\author{
Tahril $^{a^{*}}$, Paulina Taba ${ }^{b}$, Nursiah La Nafie ${ }^{\mathrm{b}}$ and Alfian Noor ${ }^{\mathrm{b}}$
}

${ }^{a}$ Chemistry Department, Tadulako University, Soekarno-Hatta Street KM. 9, Tondo, Mantikulore, Palu, Indonesia

${ }^{b}$ Chemistry Department, Hasanuddin University, Perintis Kemerdekaan Street Km 10, Tamalanrea Makassar 90245 , Indonesia

\begin{tabular}{l}
\hline C H R O N I C L E \\
\hline Article history: \\
Received August 4, 2019 \\
Received in revised form \\
October 30, 2019 \\
Accepted November 9, 2019 \\
Available online \\
November 9, 2019 \\
\hline Keywords: \\
Seagrass \\
Association \\
Fe \\
ICP-OES \\
Ecosystem \\
\hline
\end{tabular}

\begin{abstract}
A B S T R A C T
Research on the profile of $\mathrm{Fe}$ in the seagrass ecosystem has been carried out. Analysis of seawater, sediment, seagrass samples from the association of mangroves, mangroves-coral reefs and coral reefs taken in the waters of Donggala Regency was carried out using the ICPOES method (Inductively Coupled Plasma-Opticaly Emission Spectrometry). It turns out that seagrasses associated with mangroves have higher iron concentration in their ecosystem, both in waters, sediments, and in seagrass plants and will be lower in association with mangroves and their association with coral reefs. Likewise, the status of seagrass has a higher concentration of Fe than infertile status or poor status. The results become some reference to show that seagrass plants can be bio-indicators of marine waters fertility.
\end{abstract}

(C) 2020 Growing Science Ltd. All rights reserved.

\section{Introduction}

During this time heavy metal content data in waters often does not reflect the actual level of pollution and danger in living things, therefore monitoring the level of heavy metal pollution in the waters needs to be supported by monitoring of organisms' life and sediment. Monitoring on living organisms known as bioindicators, namely the use of certain types of organisms that can accumulate existing pollutants so that they represent the conditions in their environment ${ }^{1}$. Various types of organisms that live in an aquatic environment both plants and animals can be bio-indicators of metal pollution in waters and reflect the level of bioaccumulation occurs, one of the marine plants that can act as bio-indicators is seagrass. Seagrass are flowering plants (angiosperms) that have a rhizome true leaves and roots that live submerged, colonizes in a region through the deployment of fruit (ropagule) produced sexually (dioecious) $)^{2}$. According to Den Hartog ${ }^{3}$, roots in seagrasses do not function important in water extraction, because the leaves can absorb nutrients directly from the seawater and do nitrogen fixation through the root hood. Seagrass grows well in protected areas and the sand substrate is stable and close to sediments that move horizontally ${ }^{4-6}$. Seagrass growth is strongly influenced by internal factors such as physiological and metabolic conditions and external factors such

\footnotetext{
* Corresponding author.

E-mail address: tahriluntad@gmail.com (Tahril)

(C) 2020 Growing Science Ltd. All rights reserved.
}

doi: $10.5267 / j . c c l .2019 .11 .001$ 
as nutrients (nutrients) and water fertility. Environmental parameters that can affect the distribution and growth of seagrass ecosystems include; brightness, temperature, salinity, substrate and current velocity ${ }^{7,8}$.

The ecology of seagrass beds is not an isolated ecosystem but interacts with other ecosystems around it. The most important interactions of seagrass ecosystems are associated with mangrove ecosystems and coral reefs. According to Ogdem and Gladfeter [in cite Bengen ${ }^{8}$ ] and Unsworth ${ }^{9}$, there are five types of interactions between seagrass beds and mangroves and coral reefs, namely; physical, dissolved organic matter, particle organic matter, fauna migration, and human impacts. The distribution of metals in shallow marine aquatic ecosystems is also believed to occur naturally through three grooves, namely 1). waste disposal, 2). sediment, and 3). organic deposits. This has an effect on absorption metalin water and in organisms that live in water. The dynamics of metals in water and organisms living in water are often used as indicators in monitoring the metal pollution in the waters. This is due to the metal content in water that can change and is very dependent on the environment and climate $^{10}$. The presence of metals, including Fe in marine ecosystems is caused by the existence of a natural cycle which is a chain that moves metals from rock to the ground, to living organisms, to water and the water returns to the rock through the process of sedimentation. The determination of heavy metal content has been carried out by using Atomic Absorption Atom (AAS). Unfortunately, this technique cannot be used for simultaneous metal analysis. Other methods such as High Performance Liquid Chromatography (HPLC) can provide analytical methods simultaneously, but the determination of metals is generally carried out with derivatization techniques and through the preconcentration process of the column so that this technique is relatively more complicated. Progress on atomic emission spectroscopy with the discovery of new sources of excitation gave birth to chemical analysis techniques in Inductively Coupled Plasma (ICP). The source of excitation in ICP is the plasma produced from radio frequency electromagnetic waves through an induction coil. This source of excitation produces a flame with a high temperature so that it is suitable for analysis of heavy metal ${ }^{11}$. Analysis with this technique is a simultaneous analysis with a high level of accuracy and sensitivity. In addition, the analysis can be accomplished quickly, easily and often does not require preconcentration of the sample first because of the high effectiveness and detection limits that are low to the ppb range. However, the use of techniques for the analysis of heavy metals is still very limited ${ }^{12}$.

\section{Results and Discussion}

\subsection{In Aquatic Systems}

The availability of nutrients in seagrass waters, including mineral elements Fe plays an important role in maintaining the fertility of seagrass, for which its presence in the waters is very important in maintaining the stability of seagrass growth. Nutrients in seagrass waters are a limiting factor for their growth $^{13,14}$ and maintain autotrophic organisms that live in them ${ }^{15-18}$.

Table 1. Effects of association and seagrass status on iron $(\mathrm{Fe})$ concentrations in seagrass waters

\begin{tabular}{|c|c|c|c|c|c|c|c|}
\hline \multirow{2}{*}{ Status (S) } & \multicolumn{7}{|c|}{ Association (L) } \\
\hline & & L1 & & L2 & & L3 & \\
\hline \multirow{3}{*}{$\mathrm{S}$} & S1 & $\begin{array}{c}0.0780 \\
\text { B }\end{array}$ & $\mathrm{b}$ & $\begin{array}{c}0.0677 \\
\text { A }\end{array}$ & $\mathrm{a}$ & $\begin{array}{c}0.0660 \\
\text { A }\end{array}$ & $\mathrm{a}$ \\
\hline & S2 & $\begin{array}{c}0.0697 \\
\text { B }\end{array}$ & $\mathrm{a}$ & $\begin{array}{c}0.0657 \\
\mathrm{AB}\end{array}$ & $\mathrm{a}$ & $\begin{array}{c}0.0637 \\
\text { A }\end{array}$ & $\mathrm{a}$ \\
\hline & S3 & $\begin{array}{c}0.0660 \\
\text { A }\end{array}$ & $\mathrm{a}$ & $\begin{array}{c}0.0640 \\
\mathrm{~A}\end{array}$ & $\mathrm{a}$ & $\begin{array}{c}0.0633 \\
\text { A }\end{array}$ & $\mathrm{a}$ \\
\hline
\end{tabular}

Description: Based on the variance of $\mathrm{Lx} \mathrm{S}$, it is proven real. Inline numbers marked with the same capital letters and numbers in the column for each of the 3 lines marked with the same lowercase letter do not differ according to the LSD test $\alpha=0.05$.

Analysis of the variance of the effect of $\mathrm{Fe}$ concentration showed that the interaction effect of the association with seagrass status was evident. The data in Table 1 shows that Fe concentration decreases in association with coral reefs and the concentration of Fe decreases with decreasing fertility status in 
seagrass. The lowest value $(0.0633 \mathrm{ppm})$ was obtained from the treatment of the association of coral reefs with poor fertility (L3S3), and the highest $(0.0780 \mathrm{ppm})$ in the treatment of the association of mangroves with very fertile fertility rates (L1S1). This illustrates that the fertility status of seagrass fields has an effect on the concentration of Fe in seagrass waters. An overview of data processing results above show that the fertility status factors both seagrass association with mangrove, mangrove-reefs, and coral reefs can be one important indicator in determining the quality of the marine environment. The highest $\mathrm{Fe}$ concentration in seagrass waters is associated with mangroves and the lowest in seagrass waters is associated with coral reefs. The survey results also illustrate that the mangrove plants in the study area are relatively thriving in estoary areas which on land have significant agricultural activities, this is in line with Irwan's ${ }^{19}$ opinion that mangrove plants require a rather extreme growing environment, which requires salt water, muddy and always flooded in tidal range such as delta, river estuary, or muddy tidal rivers. This may cause the concentration of metals in the water in the mangrove region to be higher than the area of mangrove-coral reefs and coral reefs. According Palar ${ }^{20}$, the concentration of metals in water can vary and depends on the environment and climate, also the concentration of the metals in the water contained in the form of ions, free, couples organic ion, the ion complex.

\subsection{In the System Sediment}

Growth environment seagrasses play arole significant in maintaining the continuity of seagrass growth, including sediment. Sedimentary nutrients are in three forms, namely dissolved in the sedimentary water shaft, adsorbed on the sediment surface and is present in the structure of the sediment grains. Even though seagrasses are able to take nutrients through the leaves, the availability of nutrients in the sediment is very important in seagrass growth. Mineral Fe which is anelement essential for plant growth, accumulates in sediments so that it can be utilized by plants through absorption of roots. According to Short in Persulessy et al. ${ }^{21}$, extraction of nutrients from the water column by seagrass leaves can be considered not important when compared with nutrient extraction by roots from sediments. Analysis of variance showed that the interaction effects of association with seagrass status were evident. The results of the analysis data in Table 2 show that the association of association with seagrass status clearly influences Fe concentration in sediments in seagrass ecosystems. The results of the analysis also show that the more fertile seagrass plants, the more concentration of Fe (ppm) in the sediment. In addition, the concentration of Fe (ppm) will increase even more if there is a mangrove area (L1) compared to the mangrove-coral reef area (L2) and coral reef area (L3).

The highest average concentration of Fe was obtained in the treatment of fertile seagrass plants in the mangrove area (L1S1) with a mean value of $13671.22 \mathrm{ppm}$, and the lowest was achieved in the interaction of growth poor seagrassin the coral reef area (L3S3) with a mean value of 778,383 ppm.

Table 2. Effect of association and seagrass status on the concentration of Iron $(\mathrm{Fe})$ in sediments in seagrass ecosystems.

\begin{tabular}{|c|c|c|c|c|c|c|c|}
\hline \multirow{2}{*}{ Status (S) } & \multicolumn{7}{|c|}{ Association (L) } \\
\hline & & L1 & & L2 & & L3 & \\
\hline \multirow{3}{*}{$\mathrm{S}$} & $\mathrm{S} 1$ & $\begin{array}{c}13671.217 \\
C\end{array}$ & $\mathrm{C}$ & $\begin{array}{c}8347.967 \\
\text { B }\end{array}$ & $\mathrm{b}$ & $\begin{array}{c}4692.817 \\
\text { A }\end{array}$ & $\mathrm{c}$ \\
\hline & $\mathrm{S} 2$ & $\begin{array}{c}9640.967 \\
C\end{array}$ & B & $\begin{array}{c}4752.733 \\
\text { B }\end{array}$ & $\mathrm{a}$ & $\begin{array}{c}3259.267 \\
\text { A }\end{array}$ & $\mathrm{b}$ \\
\hline & S3 & $\begin{array}{c}5738.917 \\
\mathrm{C}\end{array}$ & A & $\begin{array}{c}4473.600 \\
\text { B }\end{array}$ & $\mathrm{a}$ & $\begin{array}{c}778.583 \\
\text { A }\end{array}$ & $\mathrm{a}$ \\
\hline
\end{tabular}


The description of the results of the processing of the data above shows that the fertility status factor of seagrasses, both in association with mangroves, mangroves and coral reefs, can be an important indicator in determining the quality of the marine environment. Seagrass plants that thrive in mangrove areas, coral reefs, and coral reefs are generally located in relatively muddy sediment areas and in the most muddy mangrove areas compared to other regions, while seagrass plants that are relatively infertile are generally located in sedimentary areas which are relatively sandy and the most sandy coral reefs compared to other regions. The results of this study also illustrate that the concentration of $\mathrm{Fe}$ in sediments is higher than that found in waters, which indicates there has been accumulation of metals in the sediment. Accumulation of heavy metals into sediments is influenced by sediment types ${ }^{20,22}$, and sediment types can affect heavy metal content in sediments, with categories of heavy metal content in sandy $>$ sandy mud $>$ sand.

\subsection{In Seagrass Plant Systems}

Iron in plants is part of an enzyme that acts as an electron carrier in photosynthesis and respiration ${ }^{23}$, needed for the synthesis of haem compounds ${ }^{24,25}$. Analysis of the variance of the effect of $\mathrm{Fe}$ concentration showed that the interaction effect of the association with seagrass status was evident. Data in Table 3 shows that the association of associations with seagrass status clearly influences $\mathrm{Fe}$ concentration in seagrass plants. The results of the analysis also show that the more fertile seagrass plants, the higher concentration of $\mathrm{Fe}(\mathrm{ppm})$ in seagrass. Moreover, the concentration of $\mathrm{Fe}(\mathrm{ppm})$ will increase significantly in mangrove (L1) compared to the mangrove- coral reef (L2) andarea reef coral (L3).

Table 3. Effect of association and seagrass status on the concentration of iron $(\mathrm{Fe})$ in seagrasses

\begin{tabular}{|c|c|c|c|c|c|c|c|}
\hline \multirow{2}{*}{ Status (S) } & \multicolumn{7}{|c|}{ Association (L) } \\
\hline & & L1 & & $\mathrm{L} 2$ & & L3 & \\
\hline \multirow{3}{*}{$\mathrm{S}$} & $\mathrm{S} 1$ & $\begin{array}{c}755.507 \\
\text { C }\end{array}$ & $\mathrm{C}$ & $\begin{array}{c}579.533 \\
\text { B }\end{array}$ & $\mathrm{c}$ & $\begin{array}{c}404.417 \\
\text { A }\end{array}$ & $\mathrm{b}$ \\
\hline & $\mathrm{S} 2$ & $\begin{array}{c}558.767 \\
\text { C }\end{array}$ & B & $\begin{array}{c}432.967 \\
\text { B }\end{array}$ & $\mathrm{b}$ & $\begin{array}{c}128.733 \\
\text { A }\end{array}$ & $\mathrm{a}$ \\
\hline & S3 & $\begin{array}{c}357.550 \\
\text { B }\end{array}$ & A & $\begin{array}{c}121.933 \\
\mathrm{~A}\end{array}$ & $\mathrm{a}$ & $\begin{array}{c}90.767 \\
\mathrm{~A} \\
\end{array}$ & $\mathrm{a}$ \\
\hline
\end{tabular}

The highest average concentration of Fe Seagrass was obtained in fertile areas in the mangrove area (L1S1) with a mean value of $755,507 \mathrm{ppm}$, and the lowest was achieved in the interaction of seagrass growth in poor areas on coral reefs (L3S3) with a mean value of 90,767 ppm. The description of the results of the processing of the data above shows that the fertility status factor of seagrasses, both in association with mangroves, mangroves and coral reefs, can be an important indicator in determining the quality of the marine environment. Various results of the previous studies show that seagrass plants can be relatively filtered in water stability because they contain macromolecular compounds that have the ability to accumulate metals in the waters. Tahril et al. ${ }^{26}$, suggested that seagrass plants contain proteins with complete amino acid composition. In response to the presence of metal elements in seagrass ecosystems, according to Prange $e t a l .{ }^{27}$ there are three important mechanisms of response to metal elements including Fe to seagrass plants in the aquatic environment, namely accumulation, toxicity, and lack/absence. Iron accumulates and forms an iron-protein complex (ferritius) which is used for photosystem II and electron transfer ${ }^{28}$. However, the absorption of excessive iron will lower the totality of amino acids so that the plant seagrass to stress ${ }^{27}$, will increase the photosensitivity of the accumulation of iron in kloroflast ${ }^{29}$, the significant reduction asparagine is the main nitrogen transfor in the addition of chelate iron ${ }^{27,30}$. 


\section{Conclusions}

Iron metal in seagrass ecosystems from coastal waters of Donggala district based on the results of analysis using ICP-OES (Inductively Coupled Plasma-Optical Emission Spectrometry), shows that:

1. Iron concentration in seagrass ecosystems is higher in status with very fertile (rich) fertility compared to the status of infertile seagrass (less rich) and poor seagrass status.

2. Seagrasses associated with mangroves have a higher iron concentration in their ecosystem, both in waters, sediments, and in seagrass plants. Iron concentrations in seagrass ecosystems will be even lower in their association with mangroves and their association with coral reefs.

3. Seagrass beds can be bio-indicators of aquatic fertility, especially heavy metals Fe.

\section{Experimental}

\subsection{Location and Time of Research}

This study was conducted in the coastal waters of Donggala Regency, Central Sulawesi Province. The study was conducted for three months. Metal analysis was planned to be carried out in the laboratory of STORMA, Faculty of Agriculture, Tadulako University and Radiation Chemistry Laboratory, MIPA Faculty, Hasanuddin University.

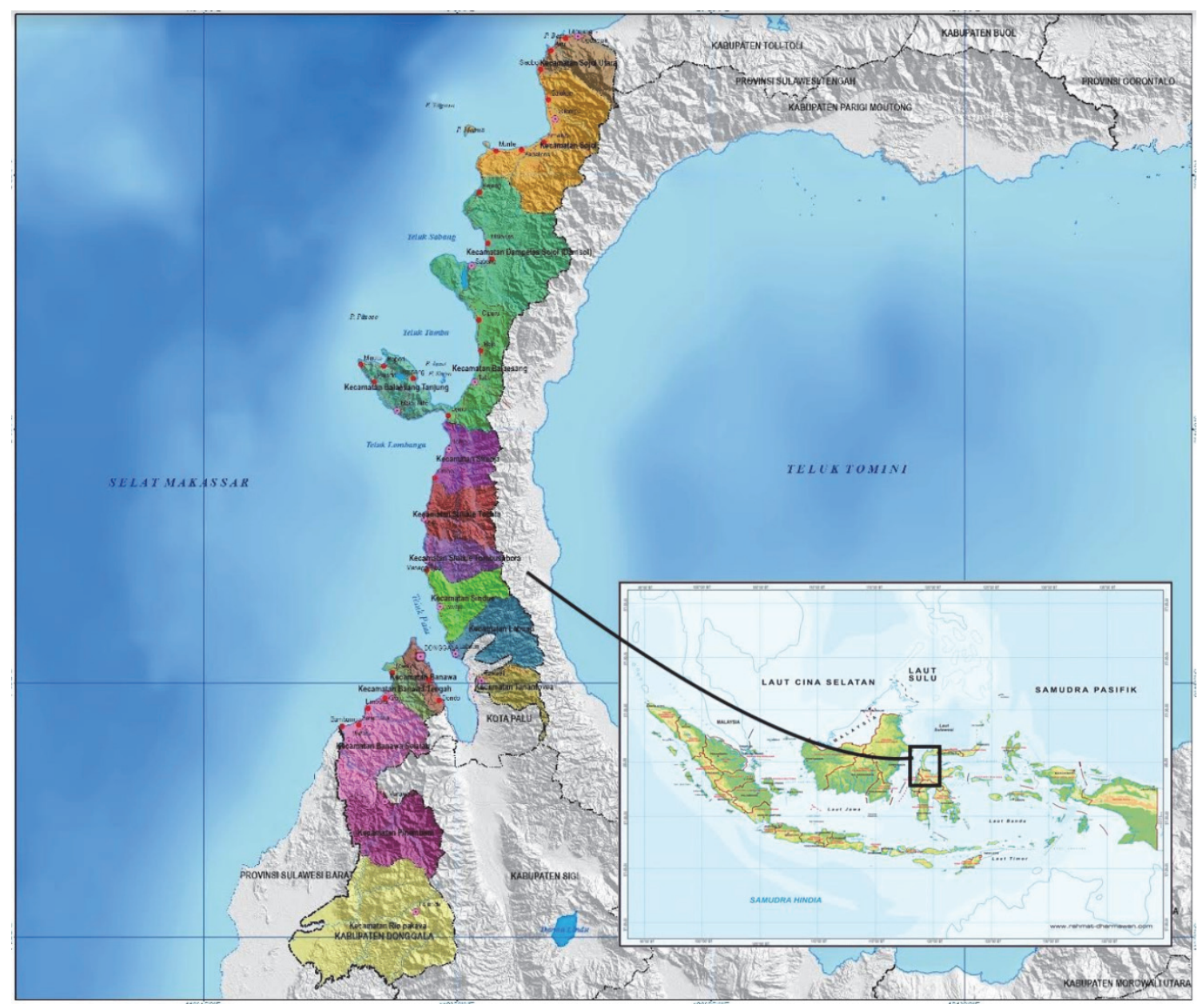

Fig. 1. The Location of Research 


\subsection{Sampling}

Sediment sampling in each seagrass status was carried out at three points in the seagrass ecosystem area, taking into account the depth of the water and the direction of the current. The zoning division is based on zoning where the depth that still allows penetrate sunlight to and the depth structure of the coastline of Donggala Regency, Central Sulawesi Province. The sampling time is the tidal state of the ocean, the transition between the first and second full moon when the tidal current is weak. This is also related to the period of the sea level and the daily tide of the sea. Along with sediment sampling, measurements were taken and samples of seagrass (species of Enhalus acorodies) taken from the sea water.

\subsection{Experimental}

Design The treatment design used was a combination of two factors, namely association of seagrass habitat $(\mathrm{L})$, namely $\mathrm{L}_{1}=$ mangrove, $\mathrm{L}_{2}=$ mangrove-coral reef, and $\mathrm{L}_{3}=$ coral reef; seagrass status $(\mathrm{S})$, which is $\mathrm{S}_{1}=$ rich, $\mathrm{S}_{2}=$ less rich, and $\mathrm{S}_{3}=$ poor. Thus obtained $2 \times 3 \times 3$ replications $=27$ treatments. The design of analysis used is a Completely Randomized Design (CRD). Data were analyzed by univariate variance. The best association and status of seagrass in determining the highest concentration of metal Fe was used BNT test $(\alpha 0,05)$.

\subsection{Working Method}

\section{Sampling and Preparation of Samples}

Sediment samples were taken using a corer sampler in the seagrass ecosystem area (front, center, and outside) which was plunged into the sediment at a predetermined point and covered with rubber plugs, then homogenized, the number of samples taken at each observation point ranged from 5-6 samples, then homogenized so that only 1 sample was obtained for each observation point. All samples taken were 9 samples per treatment group, so that a total of 27 samples ( 3 ecosystem status of seagrass beds $\times 9$ objects of observation). Along with sediment sampling, seawater and seagrass samples were also taken. The sediment samples were dried in an oven with a temperature of $105^{\circ} \mathrm{C}$ for \pm 3 days, then separated the coarse granules. Then sifted from $2 \mathrm{~mm}, 200 \mu \mathrm{m}$, to $125 \mu \mathrm{m}$ until fine grains were obtained. Weighed as much as \pm 100 mgram and put in a PTFE container, then added $2 \mathrm{~mL}$ ofHNO3 concentrated, then the PTFE container was closed tightly. Then, heated in an oven with a temperature of $200{ }^{\circ} \mathrm{C}$ for \pm 14 hours. After the sample solution becomes cold, the sample solution is filtered into a $50 \mathrm{~mL}$ volumetric flask and impregnated with easypure until the tera mark, the sample solution is ready to be measured. Seawater samples are filtered using filter paper to avoid suspended particles which can affect the burnt capillaries. Sample solution is ready to be measured. Seagrass samples are washed with distilled water until they are completely clean and then aerated, then cut into small pieces, put in a container and dried in an oven for \pm 3 days at $70{ }^{\circ} \mathrm{C}$. The dried seagrass sample is ground using a grinder (Retsch SM 2000 and ZM Retsch 100) to obtain fine samples. Weighed as much as \pm 100 mgram and put in a PTFE container, then added $2 \mathrm{~mL}$ of $\mathrm{HNO}_{3}$ concentrated, then the PTFE container was closed tightly. Then, heat it in an oven at $200{ }^{\circ} \mathrm{C}$ for \pm 14 hours. After the sample solution becomes cold, the sample solution is filtered into a $50 \mathrm{~mL}$ volumetric flask and impregnated with easypure until the tera mark, the sample solution is ready to be measured.

\section{Analysis by ICP-OES}

Form, standard raw solution, and the samples were analyzed using ICP-OES equipment at maximum wavelength of each of the elements in which the standard treatment of the standard solution and form treated as testing of samples analyzed. The results of the analysis of standard solutions made a 
calibration curve using a regression equation and then became the basis for determining the concentration of Fe metal.

\section{References}

1. Rashed, M. N. (2007). Biomarker as Indicator for Water Pollution with Heavy Metals in Rivers, Sea and Oceans. Fac. of Science.

2. Mann, K. H. (2009). Ecology of coastal waters: with implications for management. John Wiley \& Sons.

3. Den Hartog, C., \& Polderman, P. J. G. (1975). Changes in the seagrass populations of the Dutch Waddenzee. Aquat. Bot., 1, 141-147.

4. Hutomo, M., Kiswara, W., \& Azkab, M. H. (1988). The status of seagrass ecosystems in Indonesia: resources, problems, research and management. SEAGRAM I, Manila.

5. Terawaki, T., Yoshikawa, K., Yoshida, G., Uchimura, M. \& Iseki, K. (2003). Ecology and restoration techniques for Sargassum beds in the Seto Inland Sea, Japan. Mar. Pollut. Bull. 47, 198-201.

6. Schanz, A. \& Asmus, H. (2003). Impact of hydrodynamics on development and morphology of intertidal seagrasses in the Wadden Sea. Mar. Ecol. Prog. Ser. 261, 123-134.

7. Hutomo, M., Kiswara, W. \& Azkab, M. H. (1992). Status dan khasanah pengetahuan ekosistem lamun di Indonesia. (Lembaga Ilmu Pengetahuan Indonesia, 1992).

8. Bengen, D. G. (2001). Sinopsis ekosistem dan sumberdaya alam pesisir dan laut. Pus. Kaji. Sumberd. dan Laut, IPB. Bogor.

9. Unsworth, R. K. F. (2007). Aspects of the ecology of Indo-Pacific seagrass systems. (2007).

10. Darmono. (2001). Lingkungan Hidup dan Pencemaran: Hubungannya dengan Toksikologi Senyawa Logam. (Universitas Indonesia, 2001).

11. Charles, B. \& Fredeen, K. J. (1997). Concepts, instrumentation and techniques in inductively coupled plasma optical emission spectrometry. Perkin Elmer Corp.

12. Botes, P. J. (2006). Investigation of mobility of trace elements in river sediments using ICP-OES..

13. Erftemeijer, P. L. A. (1992). Factor limiting growth and production of tropical seagrasses: Nutrient dynamic in Indonesian seagrass beds (Buginesia IV). Tentat. Final Rep. Prep. LIPI WOTRO, Ujung Pandang .

14. Erftemeijer, P. L. A., Stapel, J., Smekens, M. J. E. \& Drossaert, W. M. E. (1994). The limited effect of in situ phosphorus and nitrogen additions to seagrass beds on carbonate and terrigenous sediments in South Sulawesi, Indonesia. J. Exp. Mar. Bio. Ecol. 182, 123-140.

15. Hillman, K., Walker, D. J., Larkum, A. W. D. \& Mc Comb, A. J. (1989). Productivity and Nutrient Limitation of Seagrasses. Biology of Seagrasses. Netherland.

16. Patriquin, D. G. (1972). The origin of nitrogen and phosphorus for growth of the marine angiosperm Thalassia testudinum. Mar. Biol. 15, 35-46.

17. McGlathery, K. J., Berg, P. \& Marino, R. (2001). Using porewater profiles to assess nutrient availability in seagrass-vegetated carbonate sediments. Biogeochemistry 56, 239-263.

18. Irlandi, E. A., Orlando, B. A. \& Biber, P. D. (2004). Drift algae-epiphyte-seagrass interactions in a subtropical Thalassia testudinum meadow. Mar. Ecol. Prog. Ser. 279, 81-91.

19. Irwan, Z. D. (2007). Prinsip-Prinsip Ekologi Ekosistem, Lingkungan, dan Pelestariannya. Jakarta Bumi Aksara.

20. Palar, H. (2004). Pencemaran dan Toksikologi Pencemaran Logam Berat. Rineka Cipta. Jakarta.

21. Persulessy, A.E., Pramudji \& Manik, J. (1998). Nutrien Air Poros Dalam Sedimen Berkarbonat dan Silikat di Padang Lamun Kotania (Seram Barat). in Seminar Kelautan LIPI-UNHAS Ke 1 (Balitbang Sumberdaya Lat Puslitbang Oseanologi - LIPI Ambon, 1998).

22. Korzeniewski, K. \& Neugebauer, E. (1991). Heavy metals contamination in the Polish zone of southern Baltic. Mar. Pollut. Bull. 23, 687-689.

23. Whitmarsh, J. \& Govindjee, L. (1995). Photosynthesis. Encycl. Appl. Phys. 13, 513-532.

24. Taiz, L. \& Zeiger, E. (2002). Plant Physiology. Sunderland, MA 690p (Sinauer Associates Inc 
Publishers, 2002).

25. Salisbury, F. B. \& Ross, C. W. (2003). Fisiologi Tumbuhan. Penerbit ITB Bandung.

26. Tahril, Taba, P., La Nafie, N. \& Noor, A. (2008). Peta Protein Berbagai Spesies Lamun di Pantai Kabupaten Donggala Sulawesi Tengah. Torani 4, 349-353.

27. Prange, J. A. \& Dennison, W. C. (2000). Physiological responses of five seagrass species to trace metals. Mar. Pollut. Bull. 41, 327-336.

28. Seckback, J. (1982). Ferreting out the secrets of plant ferritin-a review. J. Plant Nutr. 5, 369-394.

29. Kim, C. S. \& Jung, J. (1993). The susceptibility of mung bean chloroplasts to photoinhibition is increased by an excess supply of iron to plants: a photobiological aspect of iron toxicity in plant leaves. Photochem. Photobiol. 58, 120-126.

30. Das, P. (1997). Samantaray, S. \& Rout, G. R. Studies on cadmium toxicity in plants: a review. Environ. Pollut. 98, 29-36.

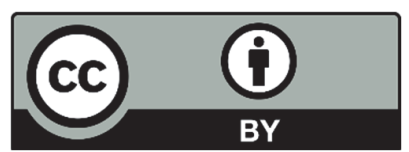

(C) 2020 by the authors; licensee Growing Science, Canada. This is an open access article distributed under the terms and conditions of the Creative Commons Attribution (CC-BY) license (http://creativecommons.org/licenses/by/4.0/). 